\begin{tabular}{lcc}
\hline Volume 5 & Number 2 & 1 JUNE 2020 \\
\hline
\end{tabular}

KRISHNAN RAMANATHAN, SARA WOLSKI, WILLIAM NOWEL, ZAIN NENSEY, MARC BARCENAS

\title{
JABIL BALANCING RISK IN A NEW FRONTIER ${ }^{1}$
}

\author{
Assessing the creditworthiness of technology startups could be a game-changer for Jabil's customer \\ expansion strategy.
}

Candy Mitchell, Information Technology Director at Jabil Inc., sank into her desk chair and looked out the window pensively. She had just finished reading a report from her team of data scientists about a predictive model they had created. She saw huge potential in this model as a potential solution to power Jabil's customer growth strategy. Part of the strategy was to engage with technology startup companies to be their partner of choice from ideation to supply chain management.

Working with technology startups would be new for Jabil and could create huge returns (when one of those technology startups took off, so would Jabil). Typical customers for Jabil (a manufacturing solutions provider that delivers comprehensive design, manufacturing, supply chain and product management services) ranged from FORTUNE® 500 s to governments.

Mitchell knew how risky startup customers could be, and Jabil only wanted to work with financially stable companies. To serve Jabil's new strategy, Mitchell placed priority on finding a way to reliably vet the startups' creditworthiness to avoid bad debt. The third-party credit rating agencies Jabil used could only provide a score for large companies with accessible financial information and history.

Mitchell's computer pinged with a calendar reminder - it was almost time for her next update meeting with her data science team. So far, their model had achieved an accuracy rate of $86 \%$. This was promising but not yet good enough. Mitchell knew they would have to address this - and soon. The faster a way to test their financial viability could be found, the sooner Jabil could partner with them and profit from them.

Mitchell wondered what impact adding more quantitative and qualitative data would have on the creditworthiness prediction model. She knew it could lead to higher accuracy, or it could lead to a redesign, which meant more time and resources. The model had to be accurate, explainable, and auditable. Was it possible to create this model internally at Jabil?

\footnotetext{
${ }^{1}$ Copyright (C) 2020, Krishnan Ramanathan, Sara Wolski, William Nowel, Zain Nensey, Marc Barcenas. This case was prepared for the purpose of class discussion, and not to illustrate the effective or ineffective handling of an administrative situation. Names and some information have been disguised. This case is published under a Creative Commons BY-NC license. Permission is granted to copy and distribute this case for non-commercial purposes, in both printed and electronic formats.
} 


\section{Jabil Inc.}

A manufacturing solutions provider that delivers comprehensive design, manufacturing, supply chain and product management services, Jabil began its legacy of creative solutions in 1966. It took its name, Jabil Circuit, from its founders, James (Jay) Golden and William (Bill) Morean. Jay and Bill met through their local community theatre in Detroit, Michigan and became friends. When Jay asked Bill for advice on a business problem (the production lines at his employer's company couldn't accommodate replacement circuit-board orders, as they were full-to-capacity producing new circuit boards), together they worked on a new way to produce the boards. This resulted in them formalizing their design as a new company that supplied the boards to Jay's former employer.

On June $5^{\text {th }}, 2017$, the name Jabil Circuit Inc. was changed to Jabil Inc. to reflect the company's service range from product design and component procurement to product testing, order fulfillment, and supply chain management. Headquartered in St. Petersburg, Florida, Jabil operated more than 100 plants globally with over 200,000 employees. The company enjoyed strong financial position in fiscal year 2019 (see Exhibit 1).

\section{Operations}

At the time the case was written, Jabil conducted business in two segments: Electronics Manufacturing Services (EMS) and Diversified Manufacturing Services (DMS) (see Exhibit 2).

The EMS segment focused on electronic manufacturing. The products Jabil made for its customers were used in the automotive, digital home, industrial and energy, networking and telecommunications, point of sale, printing, and storage businesses. This was the primary segment in which startup technology companies would partner with Jabil from ideation or at their New Product Introduction (NPI) stage.

The DMS segment focused on providing engineering solutions, with an emphasis on material sciences and technologies. It worked with customers to develop and manufacture products for consumer wearable technologies, emerging growth, healthcare, mobility, and packaging.

\section{Customer Growth}

Jabil's leadership identified a path to growth by serving a new customer segment: technology startups. Jabil recognized an opportunity in assisting technology startups with better product design (partnering with Jabil's seasoned product designers) and scaled, efficient supply chain management. These were both areas of specialty for Jabil (see Exhibit 3). If Jabil became heavily integrated in a startup's business and helped its early success, it would be a mutually profitable arrangement. However, to do business with startup companies on a continual basis, Jabil had to understand their financial risk.

The way Jabil worked with clients could vary by type of solution or engagement, as well as in contract details. For example, for customers deemed more financially stable, Jabil might have offered extended payment terms (days allowed before collecting on invoices due), trusting the company to not default on payment (preventing bad debt, or the inability to collect payments). With more risky companies, Jabil might have structured contract points differently - offering a shorter collection window for payments or requiring payment upfront or in installments.

Mitchell's role leading the data science team at Jabil meant she worked closely with strategic leaders across diverse functions to power solutions with data analytics. Not only was this project highly visible 
from the customer expansion perspective, it also had direct impacts to Jabil's bottom line. If her team could find a way to build a creditworthiness assessment tool in-house, it would power the expansion strategy and save costs from using external sources to do this.

Mitchell understood that the finance team had to protect Jabil from offering better payment terms to a customer who could not pay (bad debt) due to a cash shortage (which many startups faced) or bankruptcy. According to Jon Xavier (2012) of the Silicon Valley Business Journal, 75\% of startups failed within their first year. With larger customers, Jabil relied on third-party credit rating agencies to provide an overall score on the organization, based on its financial stability and past history. Much like a consumer was required to achieve a certain personal credit score in order to be approved for a new credit card, auto loan, or mortgage, organizations were also expected to build credit over time.

Jabil could wait for these companies to mature and build that credit score over several years, but the reason this was a captivating new market for Jabil was precisely their newness and potential for rocketing growth with new technologies that could be disruptive. This was the essence of Jabil's risk/reward in capturing this new market of customers.

\section{Creditworthiness}

Since the early 1900s, investors relied upon credit ratings to determine the financial stability of organizations, which used a variety of financial and liquidity indicators to arrive at an overall rating. Three major credit rating companies, Standard and Poor (S\&P), Moody's, and Fitch Group (also known as The Big Three Credit Rating Agencies or CRAs) all had historical origins around the same time and, at the time of publication, controlled $95 \%$ of the credit ratings business in the U.S.

\section{Historical Context}

John Moody and Company published Moody's Manual in 1900, which included information on the financial stability of stocks and bonds before expanding into credit ratings. Henry Poor began his career as an early securities analyst in his "History of Railroads and Canals in the United States," published in 1860. His company later merged with Standard Statistics, which published information about bonds and sovereign debt ratings. Standard and Poor's Corporation became a household name, thanks to the S\&P 500 stock market index. In 1924, John Knowles Fitch introduced the letter-rating system most commonly used since then (in declining order AAA, AA, A, then into BBB, BB, B, and so on). The financial indicators for each rating provider varied to a degree, with many similarities. Common factors in the calculation of ratings included liquidity, debt, profitability, working capital, and asset value indicators.

Since the global economic crisis of 2007-2009, national reforms and additional regulations (domestically and globally) were created to standardize the ratings process, rebuild trust in the system, and prevent future economic crises based on misleading, inaccurate, or incomplete credit rating information. Also, since the global economic crisis, countries' (which also receive credit ratings) credit scores have been adjusted. For example, the U.S. went from a AAA rating by Standard \& Poor to AA (see Exhibit 4).

None of these CRAs had the capacity to evaluate small, privately held corporations. In order to assess the financial stability of these organizations, one could perform an analysis called a "Probability of Default (PD) Model," if financial information was accessible. PD Models took into account factors such as historical data from financial statements and ratios (leverage, debt, profitability, asset valuation, liquidity, etc.). (For a glossary of financial terminology found in this case, please see Exhibit 5.) Using this 
information, one could create a model to predict (based on past financial data) a company's future risk and populate that model with commonly known factors to assess financial stability (Exhibit 6). However, given the volatility of startup companies, past data might not be the most useful (or plentiful) resource to accurately assess risk.

\section{Traditional Creditworthiness Factors}

Additional factors went into CRA models to assess credit, including non-financial information. Nonfinancial data could be split into two main groups, internal and external. Internal factors included items such as ownership/management. The qualifications of executive level management and their years in the industry also contributed to creditworthiness. So too did the amount of years the company had been in business, the number of branches, and the number of employees. A company managed by seasoned professionals and seeing reliable growth trends would warrant a higher credit score than a volatile startup with untested owners.

External factors were equally important to a creditworthiness score, considering the global nature of business. One external factor was the political climate. Companies operating in countries with unstable governments would generate a worse country/region risk, which would lower that company's creditworthiness score. Another external factor was the overall economic condition in the country/region. An area with large fluctuations in currency exchange rates would be problematic.

Additionally, a country or region with a steadily growing economy would return more favorable scores. Finally, another factor was the specific industry. If the company was within a stable growing industry, a better score would be given to that company.

\section{Non-Traditional Creditworthiness Factors}

There were non-traditional, creditworthiness factors to consider as well. With increased outsourcing and the transactional speed of the internet, business-to-business (B2B) transactions had been on the rise for the past 20 years. Historically, B2B exchange transactions were not a traditional factor of creditworthiness. However, data existed for companies that were members of a B2B exchange, and that data could be helpful in determining creditworthiness (see Exhibit 7). The amount of time the company had been a member of the exchange, the total number of transactions on a monthly basis, and even the amount of website customization a company had on exchange websites all pointed to strength and credibility of a potential partner to Jabil.

If Jabil data science team considered including these non-financial and non-traditional creditworthiness factors into their in-house, predictive, creditworthiness model, that information may have strengthened the model by providing more data points. Conversely, it could also have slowed progress on accuracy. If the team included these elements, the preferred regression models could change, and the team would have to dig through an ever-growing amount of data to find relevant factors, some of which might only apply to certain regions or industries.

\section{Current Credit-Rating Models}

The current CRA models used logistic regression to estimate the probability of default (PD) in a lending decision. While the exact algorithms of their various models were kept private, all three major CRAs relied on a similar process to determine the creditworthiness of an entity. 
Studies conducted on technology startups in London and South Korea found certain common financial factors that could be used to improve Jabil's model. Technology startups with higher receivables turnover (collection of accounts receivable) and strong working capital management were much less likely to default on credit terms. According to a study at the University of Brighton, the probability of default for technology startups could be as high as $36 \%$, and in cases of loans for working capital, the probability of default increased another $9.8 \%$. Startups that financed their operations from strong retained earnings and working capital were much less likely to default on loans.

The major CRA models standardized financial statements to better capture the underlying economic factors that affected creditworthiness. For companies in the Electronic Manufacturing Services (EMS) industry (like Jabil), this included reclassifying off-balance-sheet items to reflect additional debt obligations, recognizing development costs in the current year to reflect their true cost to the company, and adjusting working capital to reflect EBITDA and other financial ratios (see Exhibit 8).

The CRAs each used a methodology that assigned weights to financial ratios and factors for the entity based on their industry. For the EMS industry, the major factors included the company's revenue, EBIT, debt as a percentage of EBITDA, EBIT as a multiple of interest expense, and free cash flow compared with debt (see Exhibit 9).

The three main CRA models all considered non-financial factors in their data, which aided them in determining a credit rating. These included an analysis of the company's industry, competitiveness, opportunities for growth, and the overall prospects of the industry. They also included other factors such as country risk and entity specific factors.

The CRAs took significant time to produce a credit rating for clients. After gathering information, it typically took the typical company at least four weeks to receive a credit rating. The ratings were also geared toward stable companies. The CRA models also favored companies that had achieved economies of scale, which did not apply in the case of small startups. Finally, the major CRAs all charged significant fees for a rating, which was a bar for many, relatively illiquid startups to get rated at all.

\section{Challenges Assessing Credit with Small to Start-Up Customers}

Smaller customers such as technology start-up companies had notoriously difficult credit rating issues when compared to well established going concerns. Standard \& Poor continuously monitored the macro and micro factors affecting the technology sector and changed its rating criteria to evaluate the everchanging sector by factoring in the following considerations:

1. The companies in the technology sector had moderately high-risk cyclicality (meaning they were more sensitive to economic downturns or periods of prosperity than other industries).

2. Companies' competitive risk and growth potential was assessed and considered.

3. Companies' product quality was often standardized and their product positioning often susceptible to material changes due to frequent and rapid technological changes in the industry.

4. Many companies in the technology sector saw high Free Operating Cash Flow (FOCF) generation, which was a factor assessed with the new criteria. Also, S\&P assessed companies' FOCF-to-Debt ratio, as this industry often required high capital expenditures. Any swings in a 
company's working capital, both seasonally and over the course of the business cycle, were scrutinized as well.

Since Jabil was conducting business with smaller technology start-up companies, the above challenges assessing creditworthiness made Jabil's effort to build their own model more complex because these industry challenges had to be reflected in the credit rating assigned.

\section{The Current State of the Model}

The data science team had an existing model they continued to build and refine on a weekly basis, with periodic update meetings with Mitchell. Conceptually, the team wanted to have a model where they could input requested data from a potential client, customer, or stakeholder and have the model produce a creditworthiness score based on those inputs. The model output would generate scores with a high level of accuracy that previously could not be produced by the third-party vendors that Jabil used. So far, the model was built entirely on financial data.

The team would need to do a deeper investigation of financial factors. On top of this, the team knew it would ultimately need to integrate both traditional and non-traditional, non-financial factors to build a stronger model that could address new and emerging creditworthiness factors.

\section{Financial Inputs for the Model}

Because the three major CRAs all relied on proprietary versions of the probability of default model, Jabil's data scientists started with this foundation as well.

Jabil's model used an algorithm to measure inputs including the following:

- EBITDA

- Current Ratio

- Cash to Debt Ratio

- Return on Capital (ROC)

- Asset Turnover Ratios

Mitchell's team studied the factors the CRAs' models used in order to learn from them as they built their internal model. With this financial data, the team looked at different modeling and boosting techniques to find the best fit. Through this process, they were able to achieve an accuracy rate of $86 \%$.

The model's current strength was its ability to accurately predict companies with higher credit ratings. When the model made predictions on test data, it was able to correctly predict A through AA+ credit scores based with relative ease. Where the model struggled was with companies rated B through $\mathrm{BBB}+$. For instance, the test data had three companies which had a credit rating of BB-. The model only correctly placed one company at BB- and placed one at BB and one at B. Alarmingly, the model placed a BBB+ company, the lowest rated company in its test set, at an A rating. This kind of Type 1 error, predicting an A company when it is really a $\mathrm{BBB}+$, had serious potential consequences (see Exhibit 10).

The team realized they needed to look at other data sources in order to boost the model's accuracy. In comparison, Moody's and S\&P both had accuracy rates over 99\% (Kazemi \& Mosleh, 2012). They were able to achieve this high level of accuracy because their financial inputs looked at large companies that had revenue above a certain threshold. This lent the model inputs that were more stable over time. The 
model Jabil explored dealt with financial inputs of smaller technology startups, some of which did not have stable financials. Other startups had high volatility over short time periods, which could affect the accuracy of the model.

\section{Auditing the Model}

Mitchell knew that regardless of the types and amounts of traditional and non-traditional creditworthiness factors the model included, her team would have to be able to explain how the model worked to the audit team at Jabil. The "Black Box" metaphor in data sciences (see Exhibit 11) described a system in which one could clearly see and understand what went into the system and what came out of the system. What could not be seen or understood was how the inputs became the outputs, or how the model had interpreted the input data to determine accurate predictions.

Mitchell could not deliver a Black Box. Like all products and models created by Jabil, Mitchell's model would go through an audit process. The audit process would ask the "How" questions that a Black Box model was incapable of answering. The audit team did this for good reason. If the model were to apply a creditworthiness score to third-party vendors, then Jabil would rely on that score as part of its decision on whether or not it would do business with that entity. If Jabil decided not to do business with a vendor or company because of the model's score, it would need to be able to defend that score in order to protect itself from any liability.

Jabil was not willing to take on additional and unnecessary liability. Hence, Mitchell would answer to the audit team to make sure the model was clearly explained. This would add additional time to the project; time which Mitchell could not fully control. Although her team would work on understanding and explaining the model as they built and refined it, the audit team would have its own questions and work at its own pace. Mitchell also understood that the more complex the model became with the addition of data, the more time would be needed to understand and explain those complexities.

\section{Development of the Model}

The team faced a design challenge: The model's complexity had increased and each iteration to make it more accurate took longer. For example, it had taken the team three weeks to increase accuracy by two percent. Once the team incorporated traditional and non-traditional, non-financial factors, their work would move even slower, as they would have to search for relevant variables in the additional data. Mitchell understood that she faced a decision about developing this model in a timely manner.

\section{Continue with the Current Team}

The team could continue to work toward bolstering the current model's accuracy without making an additional investment with others' resources (time, budget). One downside to this option was completion time - the team assigned to this project completed the work when time allowed, during breaks from their full-time Jabil responsibilities and every Friday for a few hours in the afternoon. Mitchell's team had several other projects on their plate (with competing priorities) and mentored other groups of data scientists, which created a constraint on their time. By continuing this work with the current team, there was also the possibility that a better model with desired accuracy could not be established. 


\section{Hire External Consultants to Build the Model}

Mitchell would have to find the budget to do this, but by bringing in an external agency of data science consultants, Jabil could outsource the creation of a model with the desired accuracy and exact features and specifications Jabil needed. This would be a costly endeavor compared to the other options Mitchell considered, but it could be done with a rapid timeline and dedicated human resources. Jabil typically espoused a culture of internal projects like this, bringing people together for internal innovation and development opportunities, which this solution would not do, but it would be completed faster than any internal project. The team needed additional outside research and, given the current capacity of her team, hiring outside consultants could help build out the model and compare its accuracy against major CRA models.

In order to complete the model Mitchell would need to hire an IT Project Manager, a Data Scientist, and an IT Engineer. The hourly contracted rate for these job classifications, based on the 50th percentile of typical pay rates were $\$ 66$ dollars per hour for an IT Project Manager, \$57 dollars an hour for a Data Scientist, and \$28 dollars an hour for an IT Engineer. Mitchell predicted that with this team, it would take approximately six months to finish the model. At these contracted rates Mitchell's 6-month cost would be about $\$ 157,000$ dollars.

An added disadvantage of hiring consultants to develop the model related to ongoing maintenance. Since the development effort required involved thousands of lines of code, any revisions to the model would be cumbersome and would require the skills of the consultants who originally developed the model. The likelihood of needing updates was a near guarantee as the model would most likely need to refactor both the traditional and non-traditional factors as technologies changed and as time passed. This would mean keeping the same team together and paying for services when needed. If this team became permanently unavailable then Jabil would be at risk if losing the internal knowledge required to update the model when needed, leading to a model which would degrade over time and potentially become obsolete.

\section{Create an Internal Jabil Competition for a Model}

Mitchell knew the power of competition and the trendiness of gamification. Jabil comprised a network of hundreds of data scientists around the world. If she and the team created an internal competition (much like the Google data analytics competition site, Kaggle), the team could harness the collective creativity that Jabil already contained.

There were advantages to setting up a contest such as this one. Jabil could experience higher levels of employee engagement as well as strengthen communications between Jabil's data scientists across the globe. The costs of the competition would be relatively low, and Jabil could provide a cash bonus to the winning team, which would be far less than hiring additional employees or external consultants.

Additionally, Jabil would not be losing day-to-day productivity as the employees would be competing on their own time.

One of the challenges, however, was this required the IT project management office to own the execution of this competition. They would face the challenge of prioritizing this among the IT PMO (Project Management Office) and other important IT infrastructure/capability projects. Another issue with a competition was that the likelihood of receiving impartial and Black Box models was higher, and there was no guarantee that a model would be built since the competition would be voluntary. What if teams dropped out when the modeling got difficult? How much time would be wasted sifting through halfcompleted models? 


\section{Partner with the Responsible Business Alliance (RBA)}

Jabil was a proud member of the RBA, the world's largest industry coalition dedicated to corporate social responsibility in global supply chains. It was founded in 2004 and had more than 150 company members. Jabil could create a proposal to RBA's board of directors to design the model jointly.

In order to make this decision a reality, Mitchell would need to first get internal authorizations from Jabil to take the concept of the model to the RBA. Upon receiving those authorizations, she would team up with the Jabil representative to create the joint proposal. That proposal would be presented to the RBA board at their next regular meeting.

If the RBA accepted the proposal, Jabil would not have to spend nearly as many in-house resources. The RBA employed around 30 people including database managers, software technicians, and program associates. Additionally, Mitchell would not have to worry about the rigorous audit process Jabil put all products through as the model would no longer be a Jabil specific product. This would save time on the back end. The RBA had created industry tools in the past, meaning that the resources and ability already existed.

Of course, there were drawbacks with this decision. Jabil would not own their model outright. If Mitchell and Jabil executives found this model to have a first-mover advantage, that advantage would be eliminated as all RBA members would have access. If Jabil ever left the RBA, they would lose access to this model as well.

Another issue with giving up ownership was the potential for the RBA to change the goals and direction of the model. The RBA focused on sustainability in global supply chains. Their main focuses were on environmental sustainability, trafficked workers, diversity and gender, and transparency in public procurement. Mitchell's model did not immediately fit into the core focuses of the RBA. By molding the creditworthiness model to better fit RBA's initiatives, Mitchell ran the risk of losing the core benefits of the model. Did the advantages of minimal resources and increased development speed outweigh the potential of losing control of the model's design?

\section{The Decision}

Mitchell and her team had a variety of options in order to solve this dilemma for Jabil. They could:

1. Continue with their current internal development process and hope it could be finished soon with a better accuracy rate.

2. Hire external consultants to build the model and find the budget to do so.

3. Create an internal Jabil competition for a model that would leverage the global, brilliant data science minds in the organization.

4. Partner with the RBA to create a shared model.

Mitchell reached out to her team to schedule their next meeting. She would present these options to the executive team but first wanted her internal team's point of view. There was no shortage of potential here. They just needed to choose the right path for Jabil. 


\section{Biographies}
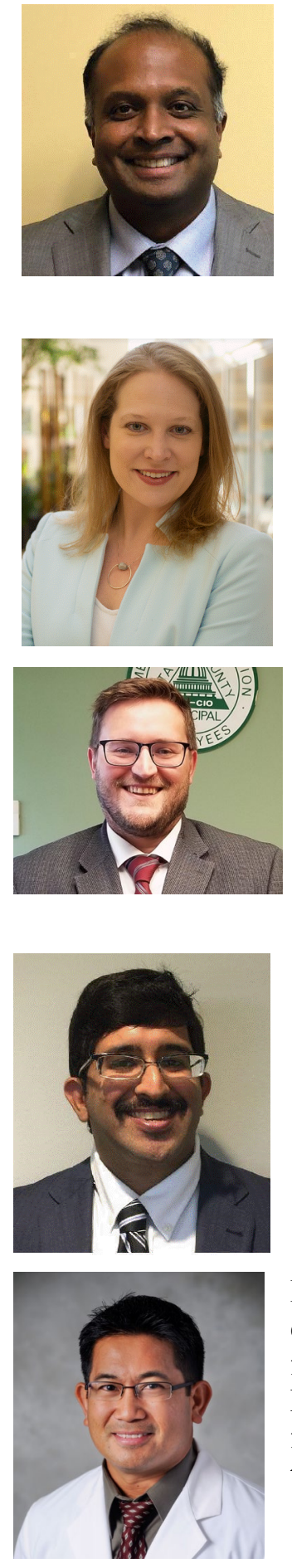

Krishnan Ramanathan, Director, Legal Lean Six Sigma at Jabil Inc. is responsible for cultivating the lean culture within the legal operations. He delivers training on Lean Six Sigma for several departments. Ramanathan received his master's degree in Mechanical Engineering from Concordia University in Montreal, Canada and his bachelor's degree in production engineering from Anna University in Chennai, India. He is completing his Executive MBA at the University of South Florida.

Sara Wolski is Vice President of Custom Design \& Consulting at Paradigm Learning, a corporate training and communications firm headquartered in downtown St. Petersburg, Florida. Previously, she was a literary agent and editorial consultant. Wolski received her bachelor's degree in fine arts from New York University and is completing her Executive MBA at the University of South Florida. In her spare time, she writes novels and screenplays.

William Nowel is the Labor Relations Manager for Hillsborough County and specializes in contract negotiations, grievance mediation and arbitration, and leadership retention. Nowel received his bachelor's degree in English from John Carroll University in Ohio and is completing his Executive MBA at the University of South Florida.

Zain Nensey is the owner of Nensey \& Associates CPAs, where he focuses on tax and accounting services for small businesses and individuals. Previously, he worked as a technical author for publications on taxation. Nensey received his bachelor's degree in accounting from the University of South Florida, where he is also completing his Executive MBA.

Marc Barcenas is an Acute Care Nurse Practitioner. With over 20 years of experience in a variety of healthcare specialties, he is currently the Clinical Director for the Urologic Oncology Center and the Men's Health program with Advent Health in Celebration, Florida. Barcenas received his bachelor's degree in nursing from St. Paul University in the Philippines and his master's degree in nursing from the University of South Florida, where he is also completing his Executive MBA. 


\section{References}

Dongre, T. \& Choudhary, B. (2018). Artificial neural network to determine the optimum nutrient media composition in plant biotechnology. Acta Scientific Agriculture 2(8). 128-135. https://doi.org/10.13140/RG.2.2.28625.22883.

Kazemi, R., \& Mosleh, A. (2012). Improving default risk prediction using bayesian model uncertainty techniques. Risk Analysis: An International Journal, 32(11), 1888-1900. https://doi-org $\underline{\text { /10.1111/j.1539-6924.2012.01915.x }}$

Moody's Ratings Methodology: Diversified Technology. (2018). Retrieved from https://www.moodys.com/researchdocumentcontentpage.aspx?docid=PBC 1130737

Safi, R. and Lin, Z. (2014). Using non-financial data to assess the creditworthiness of businesses. PACIS 2014, Retrieved from https://aisel.aisnet.org/pacis2014/206/

Xavier, J. (2012). 75\% of startups fail, but it's no biggie. Silicon Valley Business Journal. Retrieved from https://www.bizjournals.com/sanjose/blog/2012/09/most-startups-fail-says-harvard.html 
Exhibit 1: Jabil Consolidated Statements of Operation - FY 2019

\section{JABIL INC. AND SUBSIDIARIES \\ CONSOLIDATED STATEMENTS OF OPERATIONS}

(in thousands, except for per share data)

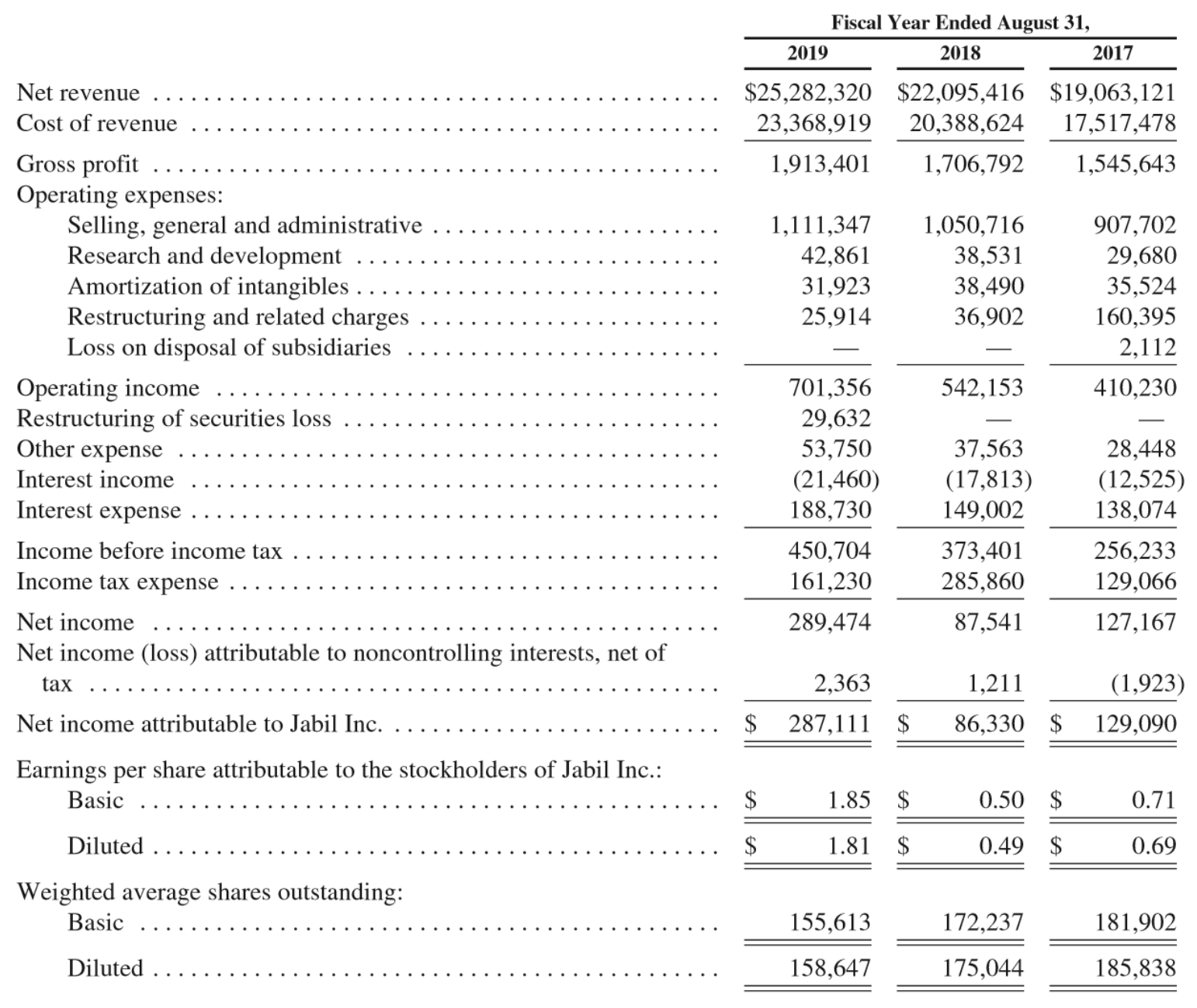

Source: Jabil Inc. 


\section{Exhibit 2: Jabil Revenue by Segment - FY 2018}

Jabil conducted business in two segments: Electronics Manufacturing Services (EMS) and Diversified Manufacturing Services (DMS).

EMS: Focused on leveraging IT, supply chain design and engineering, technologies largely centered on core electronics. The products Jabil made for its customers were used in the automotive, digital home, industrial and energy, networking and telecommunications, point of sale, printing, and storage businesses.

DMS: Focused on providing engineering solutions, with an emphasis on material sciences and technologies. It worked with customers to develop and manufacture products for consumer wearable technologies, emerging growth, healthcare, mobility, and packaging.

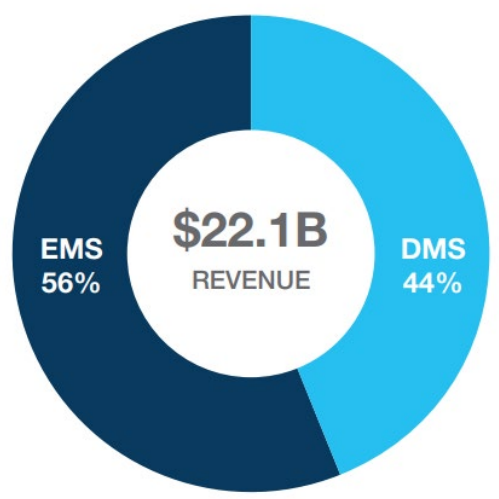

FY18 Business Mix

Source: Jabil 2018 Annual Report. Retrieved 5 September 2019 from https://investors.jabil.com/staticfiles/12603755-e47f-4546-a269-8e6beee039f8 


\section{Exhibit 3: Startup Company and Jabil Inc.}

Athos, a startup company and customer of Jabil, working with Jabil on product design and manufacturing.
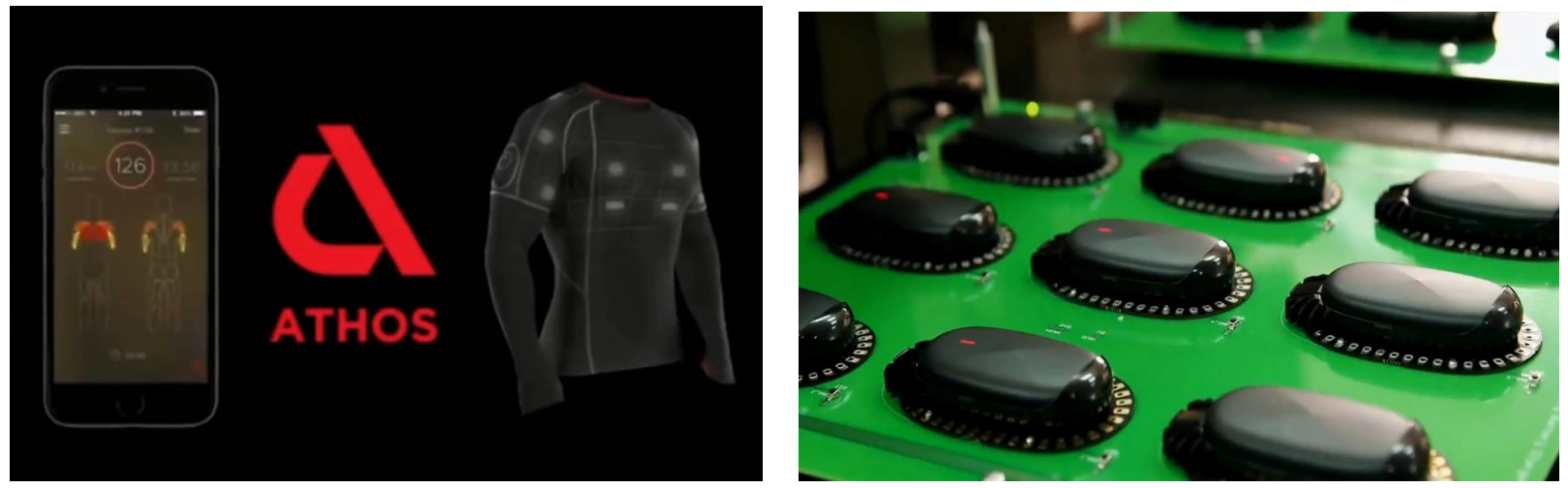

Source: "Athos, a Startup Based in Redwood City, California, is Poised to Transform the Fitness Industry." Retrieved 2 September 2019 from https://www.jabil.com/insights/case-studies/jabil-helpsathos-digitize-fitness.html. 
MUMA CASE REVIEW

\section{Exhibit 4: Credit Ratings by Country}

\section{Countries By Standard \& Poor's Credit Rating}

Standard \& Poor's credit ratings measure the creditworthiness of countries and companies. An AAA rating indicates an "extremely strong capacity to meet financial commitments," while anything below a $B B$ rating is considered speculative grade. The U.S. was downgraded from AAA to AA in the wake of the recession.

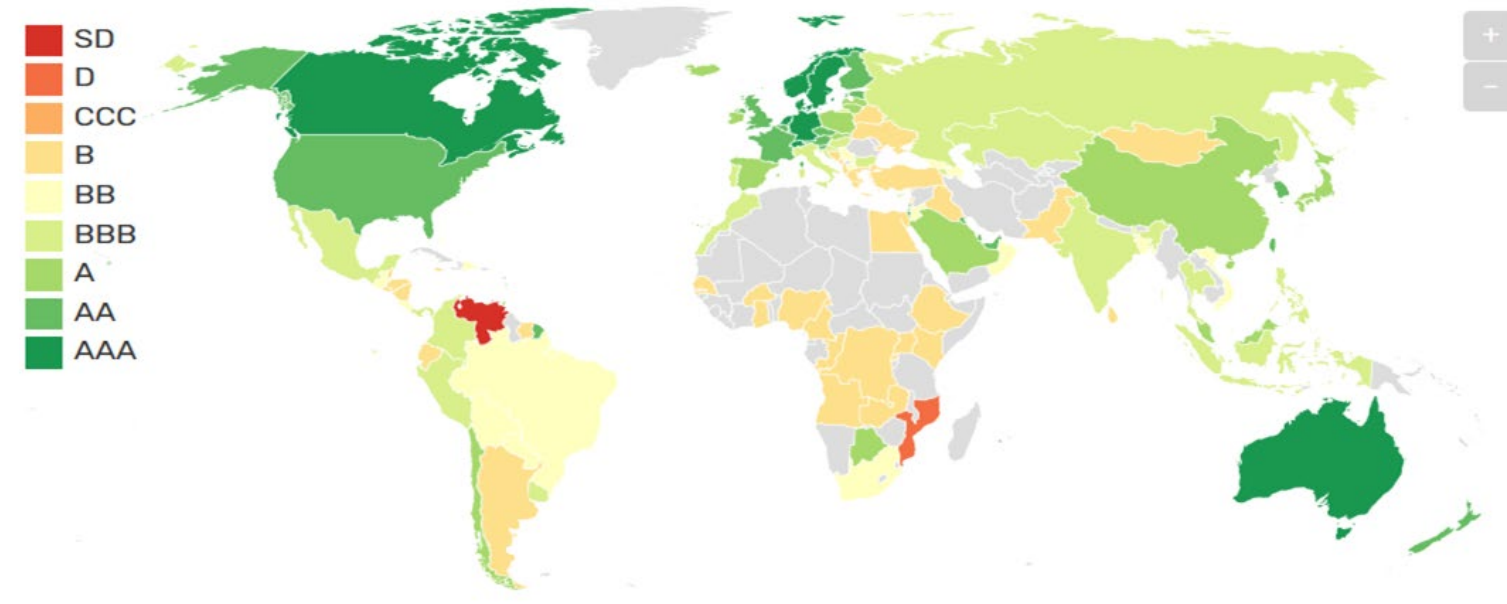

Map: The Balance • Source: Standard \& Poor's

Source: The Balance.com, https://www.thebalance.com/u-s-companies-rated-aaa-higher-than-u-sgovernment-bonds-417105 


\section{Exhibit 5: Glossary of Financial Terminology}

\begin{tabular}{|c|c|}
\hline Bad Debt & $\begin{array}{l}\text { A monetary amount (i.e., an invoice) that cannot be collected due to the customer not having } \\
\text { the ability (cash on hand) to pay it. }\end{array}$ \\
\hline Revenue & $\begin{array}{l}\text { A company's income in exchange for goods or services provided to customers (also called } \\
\text { "sales" or "top line") }\end{array}$ \\
\hline Leverage & $\begin{array}{l}\text { How a company funds growth or a return on investment, usually by borrowing money in the } \\
\text { form of a loan or with an exchange of equity }\end{array}$ \\
\hline Debt & A monetary amount a company (or individual) owes another entity \\
\hline Profitability & $\begin{array}{l}\text { A company's ability to generate excess revenue after expenses are paid through the operations } \\
\text { of the business. Also "profit" and "bottom line." }\end{array}$ \\
\hline Asset Valuation & $\begin{array}{l}\text { Determining the value of a company's assets (assets being what a company owns - cash, } \\
\text { investments, equipment, inventory, etc.) }\end{array}$ \\
\hline Liquidity & $\begin{array}{l}\text { The ease at which an asset can become cash (sold off for cash). Measuring a company's } \\
\text { liquidity is assessing how easily they can pay for things with the assets they have on hand. }\end{array}$ \\
\hline $\begin{array}{l}\text { Free Operating Cash Flow } \\
\text { (FOCF) }\end{array}$ & $\begin{array}{l}\text { A cash flow metric measured by Standard \& Poor (S\&P) that considers how well a company } \\
\text { generates cash through its operations as part of the overall assessment of its credit rating }\end{array}$ \\
\hline Current Ratio & $\begin{array}{l}\text { A measure of a company's liquidity, taking into consideration its short-term assets that could } \\
\text { turn into cash (inventory, accounts receivable - amounts due to the company from invoices sent } \\
\text { to their customers) compared to its liabilities (what it owes) }\end{array}$ \\
\hline Cash Ratio & Measures a company's cash (liquidity) in comparison with its liabilities (debt) \\
\hline Asset Turnover Ratio & Measures how well a company is using its assets to generate revenue. \\
\hline EBITDA & $\begin{array}{l}\text { Earnings Before Interest, Taxes, Depreciation, and Amortization - a measure of a company's } \\
\text { ability to generate a profit through their operations (also referred to as "operating profit") }\end{array}$ \\
\hline Debt Ratio & $\begin{array}{l}\text { A financial ratio that measures the amount of debt a company has compared to its assets (also } \\
\text { applies to individuals as a "Debt to Income" ratio) }\end{array}$ \\
\hline Receivables Turnover & The rate at which companies collect accounts receivable. \\
\hline Probability of Default (PD) & $\begin{array}{l}\text { PD is the risk that the borrower will be unable or unwilling to repay its debt in full or on time. } \\
\text { The risk of default is derived by analyzing the obligor's capacity to repay the debt in } \\
\text { accordance with contractual terms. It is measured by analysis of the borrower's capacity to } \\
\text { repay debts. PD is generally associated with financial characteristics such as insufficient cash } \\
\text { flow, falling revenues or operating margins, high amounts of debt, declining or marginal } \\
\text { liquidity, and the success of the company's business model. The probability of default also } \\
\text { must measure the borrower's willingness to repay. }\end{array}$ \\
\hline
\end{tabular}

Source: Investopedia.com, https://www.investopedia.com/, retrieved September 19, 2019 
MUMA CASE REVIEW

\section{Exhibit 6: Factors to Assess Financial Stability}

Table 1: Drivers of weak credit score in CreditModel and PD Model Fundamentals. Dataset includes circa 67K scores "worse than b-", between 2006 and 2016, for non-financial corporate companies domiciled in NorthAmerica.

\begin{tabular}{|c|c|c|c|}
\hline \multicolumn{2}{|c}{ Model } & \multicolumn{2}{c|}{ Drivers of weak credit score } \\
\hline \hline CreditModel 2.6 Corporates & $\begin{array}{c}\text { Total Assets } \\
\text { (Size) }\end{array}$ & $\begin{array}{c}\text { EBITDA / Revenues } \\
\text { (Profitability) }\end{array}$ & $\begin{array}{c}\text { Debt / Capital } \\
\text { (Leverage) }\end{array}$ \\
\hline $\begin{array}{c}\text { PD Model Fundamentals - } \\
\text { Public Corporates }\end{array}$ & $\begin{array}{c}\text { Total Equity } \\
\text { (Size) }\end{array}$ & $\begin{array}{c}\text { EBIT / Revenues } \\
\text { (Profitability) }\end{array}$ & $\begin{array}{c}\text { Retained Earnings / Total Assets } \\
\text { (Flexibility) }\end{array}$ \\
\hline $\begin{array}{c}\text { PD Model Fundamentals - } \\
\text { Private Corporates }\end{array}$ & $\begin{array}{c}\text { Total Revenues } \\
\text { (Size) }\end{array}$ & $\begin{array}{c}\text { Net Income / Revenues } \\
\text { (Profitability) }\end{array}$ & $\begin{array}{c}\text { Current Liabilities / Net Worth } \\
\text { (Short-term Leverage) }\end{array}$ \\
\hline
\end{tabular}

Source: S\&P Global Market Intelligence, as of October 31 2016. 


\section{Exhibit 7: Classification of Creditworthiness-Related Data}

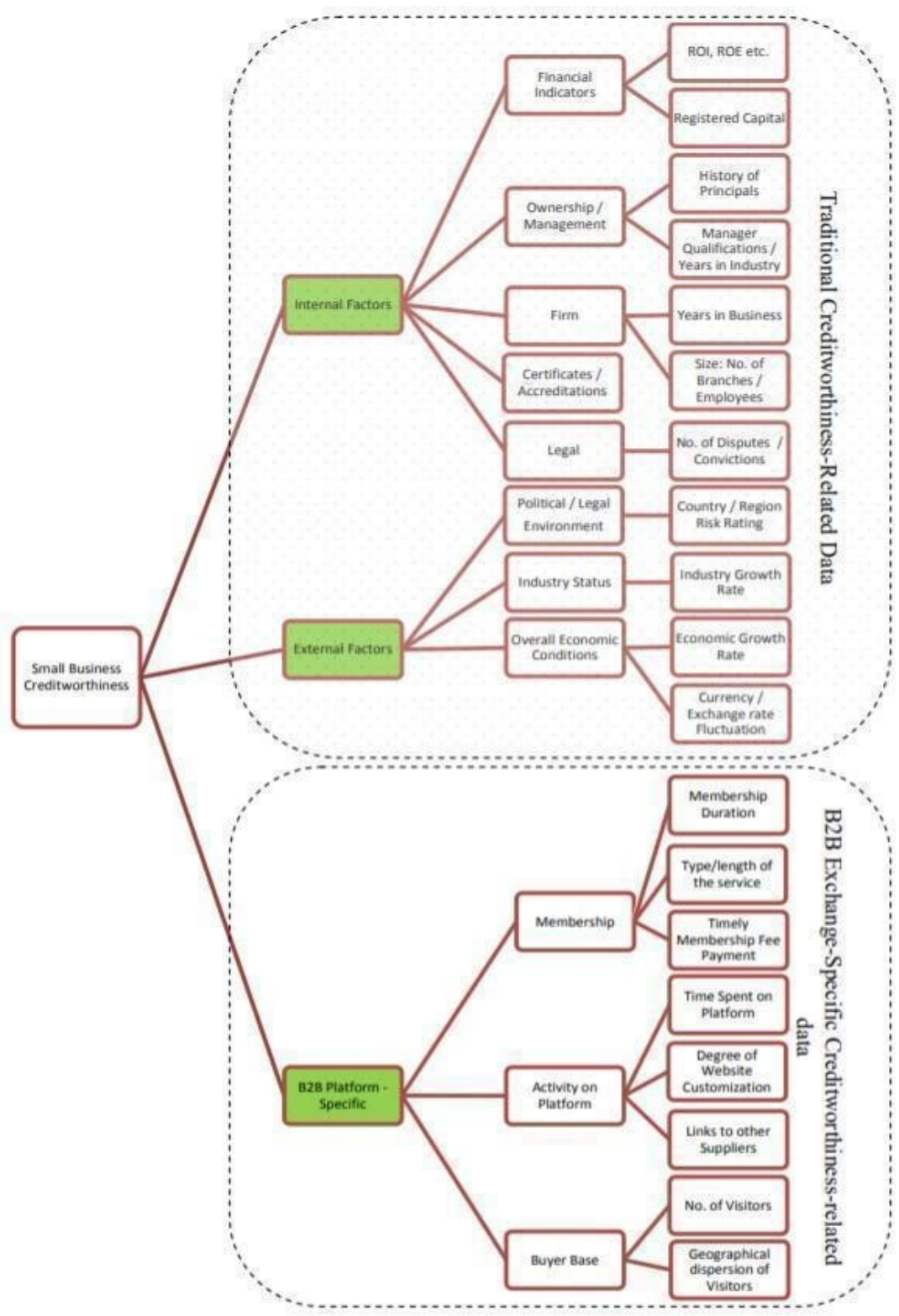

Source: Using non-financial data to assess the creditworthiness of businesses in online trade. (Safi \& Lin, 2014). 
MUMA CASE REVIEW

\section{Exhibit 8: Moody's Financial Statement Adjustments}

\begin{tabular}{|c|c|}
\hline Adjustment & Purpose \\
\hline $\begin{array}{l}\text { Defined benefit } \\
\text { pension plans }\end{array}$ & $\begin{array}{l}\text { To eliminate the effects of artificial smoothing of pension expense permitted by accounting standards } \\
\text { and recognize as debt the amount the pension obligation is underfunded or unfunded (subject to } \\
\text { equity credit). We also change the classification of cash contributed to the pension trust on the cash } \\
\text { flow statement under certain circumstances. }\end{array}$ \\
\hline $\begin{array}{l}\text { Multiemployer } \\
\text { pension plans }\end{array}$ & $\begin{array}{l}\text { To recognize as debt an estimate of the company's portion of an underfunded multiemployer pension } \\
\text { liability. }\end{array}$ \\
\hline $\begin{array}{l}\text { Operating leases } \\
\text { (off balance sheet) }\end{array}$ & $\begin{array}{l}\text { To capitalize operating and off-balance sheet finance leases and recognize a related debt obligation. } \\
\text { We re-characterize rent expense on the income statement by imputing interest on lease debt and } \\
\text { considering the residual amount as depreciation and make corresponding adjustments to the cash } \\
\text { flow statement. }\end{array}$ \\
\hline $\begin{array}{l}\text { Leases (on balance } \\
\text { sheet) }\end{array}$ & $\begin{array}{l}\text { To recognize lease liabilities as debt obligations on the balance sheet (if not already classified as debt). } \\
\text { For US GAAP operating leases, we re-characterize rent expense on the income statement by imputing } \\
\text { interest on lease debt and considering the residual amount as depreciation, with corresponding cash } \\
\text { flow statement adjustments. We reclassify principal payments into capital expenditure in investing } \\
\text { cash flows. }\end{array}$ \\
\hline Capitalized interest & $\begin{array}{l}\text { To expense interest capitalized in the current year. On the cash flow statement, we reclassify } \\
\text { capitalized interest from an investing cash outflow to an operating cash outflow. }\end{array}$ \\
\hline $\begin{array}{l}\text { Capitalized } \\
\text { development costs }\end{array}$ & $\begin{array}{l}\text { To expense development costs capitalized in the current year and adjust intangible assets on the } \\
\text { balance sheet accordingly. On the cash flow statement, we reclassify capitalized development costs } \\
\text { from an investing cash outflow to an operating cash outflow. }\end{array}$ \\
\hline $\begin{array}{l}\text { Interest expense } \\
\text { related to } \\
\text { discounted long- } \\
\text { term liabilities other } \\
\text { than debt }\end{array}$ & $\begin{array}{l}\text { To adjust interest expense to reclassify the accretion of discounted long-term liabilities other than } \\
\text { debt as an operating expense. }\end{array}$ \\
\hline Hybrid securities & $\begin{array}{l}\text { To classify securities with characteristics of both debt and equity in accordance with Moody's } \\
\text { classification of hybrid securities, which sometimes differs from accounting treatment. We adjust } \\
\text { interest expense, dividends and related cash flows consistent with our classification of the hybrid } \\
\text { security. }\end{array}$ \\
\hline $\begin{array}{l}\text { Securitizations and } \\
\text { factoring } \\
\text { arrangements }\end{array}$ & To classify off-balance sheet securitization and factoring arrangements as collateralized borrowings. \\
\hline $\begin{array}{l}\text { Inventory reported } \\
\text { on a LIFO cost basis }\end{array}$ & To adjust inventory recorded on a LIFO cost basis to FIFO value. \\
\hline $\begin{array}{l}\text { Consistent } \\
\text { measurement of } \\
\text { Funds from } \\
\text { Operations }\end{array}$ & $\begin{array}{l}\text { To adjust working capital where appropriate to include the difference between tax paid and current } \\
\text { tax expense, and net interest paid and interest expense. }\end{array}$ \\
\hline $\begin{array}{l}\text { Unusual and non- } \\
\text { recurring items }\end{array}$ & $\begin{array}{l}\text { To reclassify the effects of unusual or non-recurring transactions and events to a separate category } \\
\text { on the income and cash flow statements. Our analytical ratios that include income or operating cash } \\
\text { flows generally exclude amounts in those separate categories. }\end{array}$ \\
\hline
\end{tabular}

Source: Moody's Ratings Methodology: Diversified Technology. (2018). Retrieved 9 September 2019 from https://www.moodys.com/researchdocumentcontentpage.aspx?docid=PBC 1130737 
RAMANATHAN, WOLSKI, NOWEL, NENSEY, BARCENAS

Exhibit 9: Moody's Model and Financial Factor Weights

\begin{tabular}{lclr} 
Broad Rating Factor & Factor Weighting & Rating Sub-Factor & Sub-Factor Weighting \\
\hline Scale & $20 \%$ & Revenue & $10 \%$ \\
\hline Business Profile & & EBIT & $10 \%$ \\
\hline Profitability \& Efficiency & $15 \%$ & Business Profile & $15 \%$ \\
\hline & $20 \%$ & EBITDA Margin & $10 \%$ \\
\hline Leverage and Coverage & & Operating Income ROA (Net of Cash $\left.{ }^{5}\right)$ & $10 \%$ \\
\hline & $30 \%$ & Debt / EBITDA & $10 \%$ \\
\hline Financial Policy & & EBIT / Interest Expense & $10 \%$ \\
\hline Total & & FCF / Debt & $10 \%$ \\
\hline
\end{tabular}

Source: Moody's Ratings Methodology: Diversified Technology. (2018). Retrieved 9 September 2019 from https://www.moodys.com/researchdocumentcontentpage.aspx?docid=PBC 1130737 
Exhibit 10: Model Test Results

\begin{tabular}{|c|c|c|c|c|c|c|c|c|c|c|c|c|c|c|c|}
\hline \multicolumn{16}{|c|}{ Reference } \\
\hline Prediction & A & A- & $A+$ & $\mathrm{AA}$ & $\mathrm{AA}-$ & $\mathrm{AA}+$ & B & B- & $\mathrm{B}+$ & BB & BB- & $\mathrm{BB}+$ & BBB & BBB- & $\mathrm{BBB}+$ \\
\hline A & 5 & 0 & 0 & 0 & 0 & 0 & 0 & 0 & 0 & 0 & 0 & 1 & 0 & 0 & 1 \\
\hline A- & 0 & 12 & 0 & 0 & 0 & 0 & 0 & 0 & 0 & 0 & 0 & 1 & 0 & 0 & 0 \\
\hline $\mathrm{A}+$ & 0 & 0 & 4 & 0 & 0 & 0 & 0 & 0 & 0 & 0 & 0 & 0 & 0 & 0 & 0 \\
\hline $\mathrm{AA}$ & 0 & 0 & 0 & 0 & 0 & 0 & 0 & 0 & 0 & 0 & 0 & 0 & 0 & 0 & 0 \\
\hline$A A-$ & 0 & 0 & 0 & 0 & 0 & 0 & 0 & 0 & 0 & 0 & 0 & 0 & 0 & 0 & 0 \\
\hline $\mathrm{AA}+$ & 0 & 0 & 0 & 0 & 0 & 1 & 0 & 0 & 0 & 0 & 0 & 0 & 0 & 0 & 0 \\
\hline B & 0 & 0 & 0 & 0 & 0 & 0 & 0 & 0 & 0 & 0 & 1 & 0 & 0 & 0 & 0 \\
\hline B- & 0 & 0 & 0 & 0 & 0 & 0 & 0 & 0 & 0 & 0 & 0 & 0 & 0 & 0 & 0 \\
\hline $\mathrm{B}+$ & 0 & 0 & 0 & 0 & 0 & 0 & 0 & 0 & 0 & 0 & 0 & 1 & 0 & 0 & 0 \\
\hline BB & 0 & 0 & 0 & 0 & 0 & 0 & 0 & 0 & 2 & 11 & 1 & 0 & 0 & 0 & 0 \\
\hline BB- & 0 & 0 & 0 & 0 & 0 & 0 & 0 & 0 & 0 & 0 & 1 & 0 & 0 & 0 & 0 \\
\hline $\mathrm{BB}+$ & 0 & 0 & 0 & 0 & 0 & 0 & 0 & 0 & 0 & 0 & 0 & 3 & 1 & 0 & 0 \\
\hline BBB & 0 & 0 & 0 & 0 & 0 & 0 & 0 & 0 & 0 & 0 & 0 & 1 & 5 & 0 & 0 \\
\hline BBB- & 0 & 0 & 0 & 0 & 0 & 0 & 0 & 0 & 0 & 0 & 0 & 0 & 2 & 7 & 1 \\
\hline BBB+ & 0 & 0 & 0 & 0 & 0 & 0 & 0 & 0 & 0 & 0 & 0 & 0 & 0 & 2 & 4 \\
\hline
\end{tabular}

Source: Jabil Inc. 


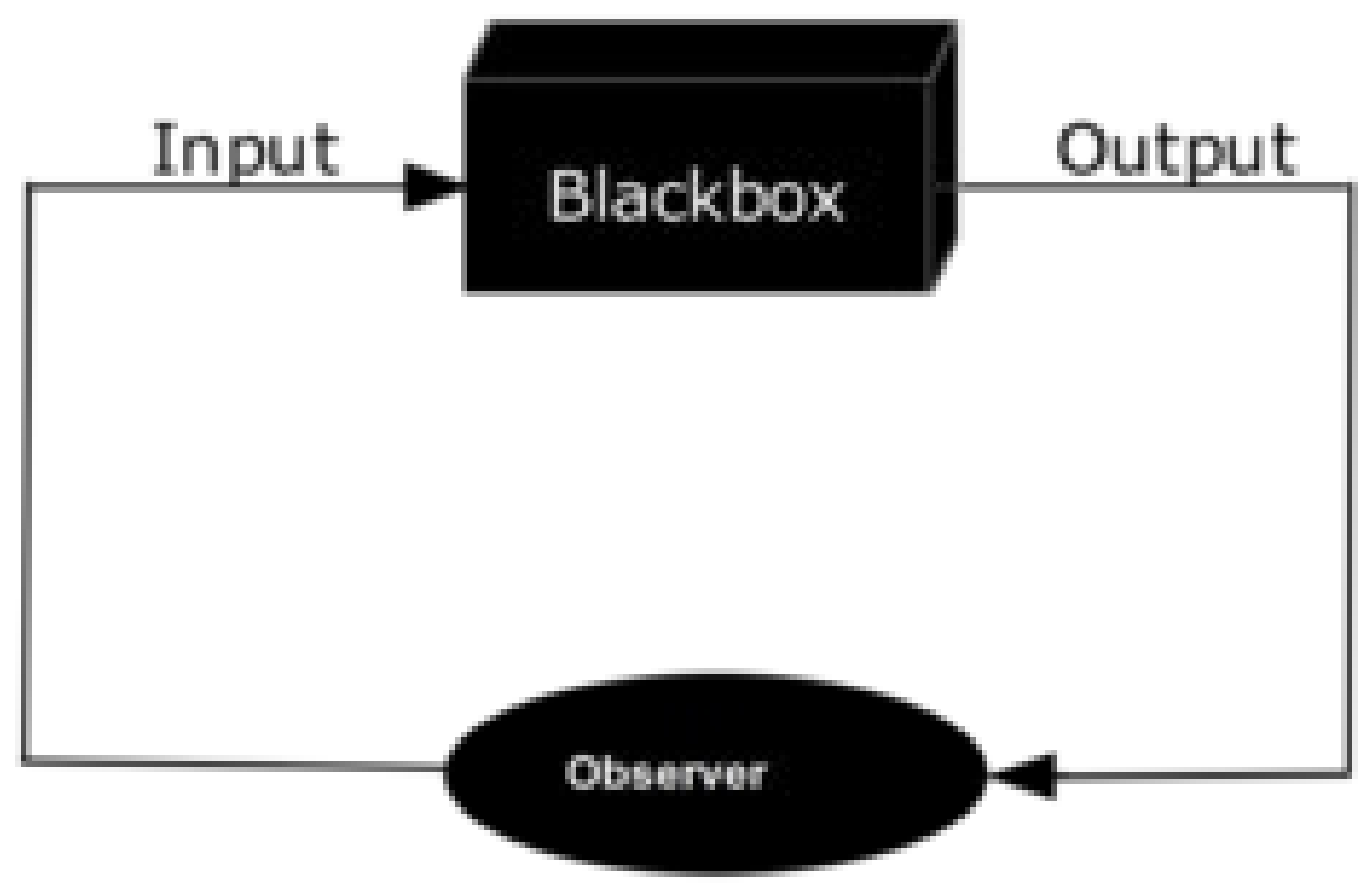

Source: Dongre (2018). 